\title{
CANADA AND THE FIRST WORLD WAR
}

\author{
Second Edition
}

The First World War is often credited with being the event that gave Canada its own identity, distinct from that of Britain, France, and the United States. Less often noted, however, is that it was also the cause of a great deal of friction within Canadian society. Canada and the First World War examines how Canadians experienced the war and how those experiences were shaped by region, politics, gender, class, and nationalism.

This second edition of Canada and the First World War includes a new introduction reviewing historical perspectives written about the war since the book first appeared in 2005. The essays themselves bring together some of the leading voices in Canadian history to take an indepth look into the tensions and fractures the war caused, and to address the way some attitudes about the country were changed, while others remained the same. They vary in scope, but are strongly unified so as to create a collection that treats its subject in a complete and comprehensive manner.

This collection, a tribute to one of Canada's greatest authorities on the First War World War, historian Robert Craig Brown, is a significant contribution to the ongoing re-examination of Canada's experiences in war, and a must-read for students of Canadian history.

DAVID MACKenzie is a professor in the Department of History at Ryerson University. 


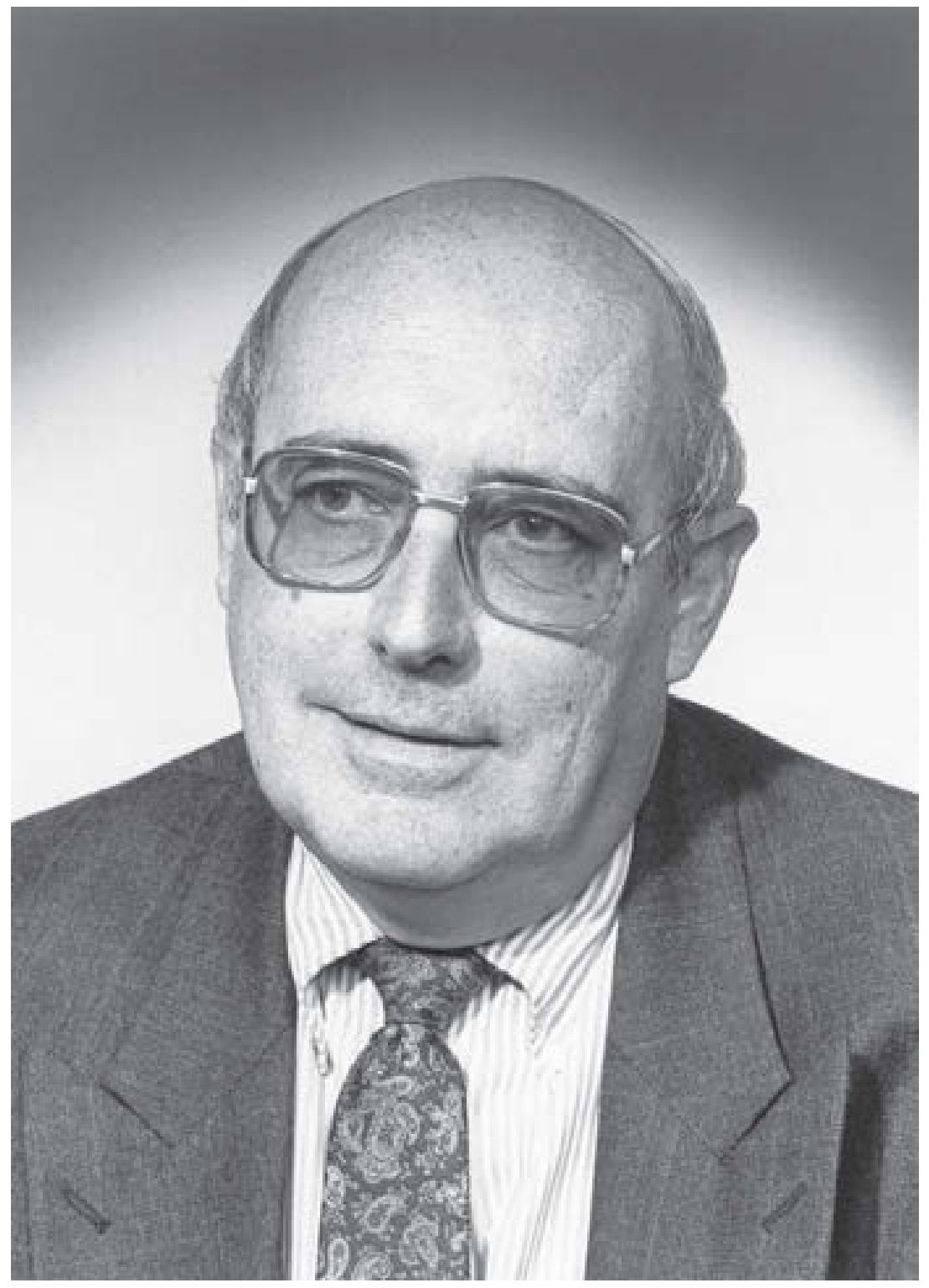

Robert Craig Brown (Office of the Dean of Arts and Sciences, University of Toronto) 


\section{Canada and the \\ First World War}

\section{Essays in Honour of \\ Robert Craig Brown}

Second Edition

Edited and with a new introduction by David MacKenzie

UNIVERSITY OF TORONTO PRESS

Toronto Buffalo London 
(C) University of Toronto Press 2005

Toronto Buffalo London

utorontopress.com

Printed in the U.S.A.

Reprinted 2014

Second Edition with a new introduction 2018

ISBN 978-1-4875-2321-3

$\otimes$ Printed on acid-free, $100 \%$ post-consumer recycled paper with vegetable-based inks.

\section{Library and Archives Canada Cataloguing in Publication}

Canada and the First World War : essays in honour of Robert Craig Brown/ edited by David MacKenzie. - Second edition.

Includes bibliographical references and index.

ISBN 978-1-4875-2321-3 (softcover.)

1. World War, 1914-1918 - Canada. I. Brown, Robert Craig, 1935-2016, honouree II. MacKenzie, David (David Clark), 1953-, editor

D547.C2C3423 $2018 \quad 940.3^{\prime} 71 \quad$ C2018-5279-1

University of Toronto Press acknowledges the financial assistance to its publishing program of the Canada Council for the Arts and the Ontario Arts Council, an agency of the Government of Ontario.

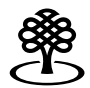

Canada Council for the Arts

Funded by the Financé par le Government gouvernement of Canada
Conseil des Arts du Canada
ONTARIO ARTS COUNCIL CONSEIL DES ARTS DE L'ONTARIO

an Ontario government agency un organisme du gouvernement de l'Ontario 